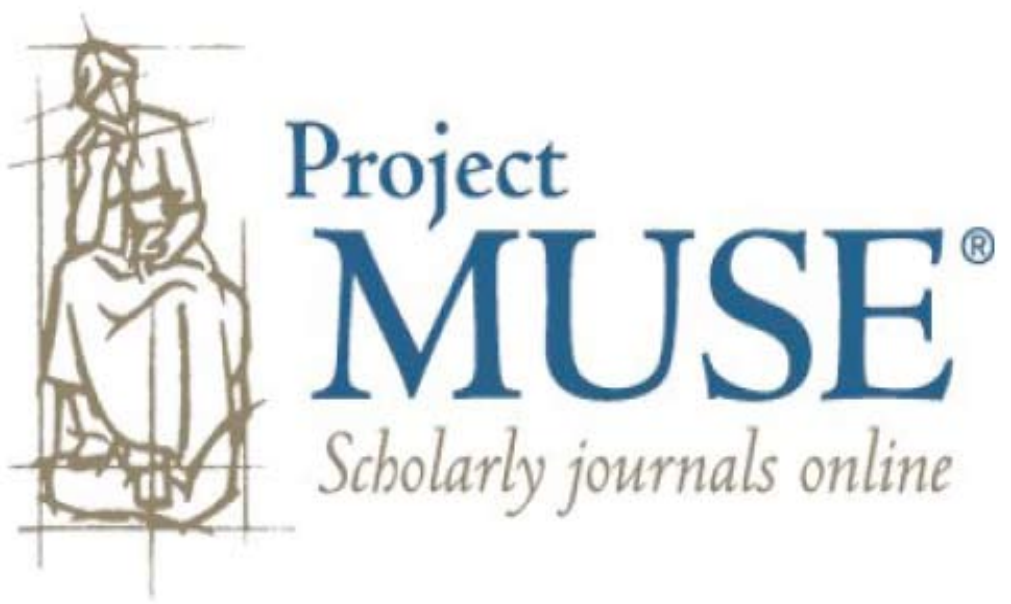




\title{
Is Kazukuru Really Non-Austronesian?
}

\author{
Michael Dunn \\ RADBOUD UNIVERSITY NIJMEGEN \\ MAX PLANCK INSTITUTE FOR PSYCHOLINGUISTICS \\ Malcolm Ross
}

AUSTRALIAN NATIONAL UNIVERSITY

\begin{abstract}
Kazukuru is an extinct language, originally spoken in the inland of the western part of the island of New Georgia, Solomon Islands, and attested by very limited historical sources. Kazukuru has generally been considered to be a Papuan, that is, non-Austronesian, language, mostly on the basis of its lexicon. Reevaluation of the available data suggests a high likelihood that Kazukuru was in fact an Oceanic Austronesian language. Pronominal paradigms are clearly of Austronesian origin, and many other aspects of language structure retrievable from the limited data are also congruent with regional Oceanic Austronesian typology. The extent and possible causes of Kazukuru lexical deviations from the Austronesian norm are evaluated and discussed.
\end{abstract}

1. INTRODUCTION. ${ }^{1}$ The Kazukuru language was recorded in the early twentieth century, when its speakers were in the last stages of language shift. The Kazukuru people had already merged culturally and politically with the Roviana people of the Roviana lagoon (New Georgia, western Solomons), and the language had fallen out of daily use. "Kazukuru" is now used as the name of a clan ("tribe" in local terminology) of the Roviana people. The major source of Kazukuru data was collected by Waterhouse and published by Ray (Waterhouse and Ray I93I); apart from this, two short word lists were published by Lanyon-Orgill that come from languages similar to (arguably, identical to) Kazukuru, purportedly spoken in the eastern parts of New Georgia (Lanyon-Orgill I953:I25).

Knowledge of Kazukuru among contemporary Kazukuru-Roviana elders is maintained using secondary materials, prominently those from Waterhouse and Ray (I93I). Hall in I964 reported that he had "not been able to add one more word to the lists obtained by Mr. Waterhouse and others" (p. I29).

It has generally been assumed that Kazukuru was a Papuan (i.e., non-Austronesian) language, but we will argue here that there is evidence that it was quite closely related to its

I. We would like to thank Bethwyn Evans, Angela Terrill, and Ger Reesink for helpful discussion of the contents of this paper, and John Lynch and an anonymous reviewer for comments that have led to substantive improvements. Disclaimer: This article presents the authors' interpretation of the purely linguistic aspects of Kazukuru for the purposes of language classification. It is based on fragmentary evidence, and is not appropriate as evidence for establishing customary land tenure under Solomons Island law, or for any other political or economic use. 
immediate neighbors and like them was a member of the Oceanic subgroup of Austronesian (henceforth "Oceanic"). In I93I, Waterhouse and Ray made the observation that "some of the [Kazukuru] words noted as resembling Roviana may be possibly related to Melanesian [i.e., Oceanic], but with these exceptions the vocabulary seems quite unlike any of the Melanesian or Papuan languages of the Solomons" (Waterhouse and Ray I93I:I24). This is hardly a categorical statement that Kazukuru is Papuan, but it was read this way by later scholars, and has not been questioned since. Lanyon-Orgill (I953) refers to Kazukuru without any qualification as "Papuan," and also gives data for two putative sister languages, Guliguli and Dororo (discussed in 3.3). We will question whether the language attested in these word lists is truly distinct from Kazukuru. Capell (I954) mentions Kazukuru in a report to the South Pacific Commission, but only comments that "the language does not seem to have been Melanesian [i.e., Oceanic]" (I954:82). He also discusses data from Kazukuru in his paper Non-Austronesian Languages of the British Solomons (Capell 1969). His discussion of possible noun class markers in Kazukuru (a typical feature of Papuan languages of island Melanesia; Terrill 2002) is evaluated in 4.4. Wurm (1982) unequivocally puts Kazukuru, Guliguli, and Dororo in his East Papuan Phylum.

This paper will show that certain structural features of Kazukuru are distinctively Oceanic, despite its having a lexicon that is highly aberrant for an Oceanic language, and that the most plausible account of the history of Kazukuru is that it is descended from an Oceanic language. If Kazukuru really were a Papuan language, it would be one of only five in the central Solomon Island archipelago, which would make it rather exotic and important in the linguistic history of the region. As an aberrant Oceanic language it is no less interesting, and its analysis may shed light on the histories of other languages of unclear affiliation in Melanesia. The classificatory problem posed by Kazukuru echoes the drawn-out debate about the affiliation of the Reefs-Santa Cruz languages (Lincoln I978; Wurm I978; Næss 2006), as well as recent queries about the languages of Utupua and Vanikoro (raised by Alexandre François 2006). In all these cases the language in question appears to have a lexicon that is wildly aberrant for an Oceanic language, but to show, to a greater or lesser degree, familiar Oceanic structural features.

We will consider four explanations of the history of Kazukuru, to the effect that Kazukuru as it was recorded in the early twentieth century was one of the following:

a Papuan language that has converged with neighboring Oceanic languages;

a mixed Papuan-Oceanic language produced by the same sort of extreme mechanisms that produced, for example, Copper Island Aleut (Golovko 1994);

a linguistic chimera, that is, a language in the last stages of language death, where speakers remember some aspects of the language, but otherwise supplement their partial linguistic knowledge with the replacement language (cf. language obsolescence, Schmidt 1985);

an Oceanic language that has diverged significantly from other Oceanic languages of the region. Possible reasons for this divergence would include:

- esoterogeny, endogenous processes of differentiation from other languages in the contact zone (Thurston I982).

- substrate influence, the outcome of shift by speakers of a Papuan language to an Oceanic language. 
The main aim of this paper is to build up a combined sociolinguistic and typological profile of the Kazukuru language, and match it against the explanatory scenarios listed above.

2. WHO SPOKE KAZUKURU, AND WHERE? Research into the archaeology and oral history of New Georgia since the publication of the Kazukuru linguistic data has clarified the causes and chronology of the migration from the inland to the coast (Aswani 2000; Sheppard, Walter, and Nagaoka, 2000; Thomas, Sheppard, and Walter 200I; Aswani and Sheppard 2003; Bayliss-Smith, Hviding, and Whitmore 2003; Sheppard, Walter, and Aswani 2004; Walter, Thomas, and Sheppard 2004). In this section we summarize what can be reconstructed of the past sociolinguistic situation of Kazukuru, giving us the context to judge whether particular patterns of linguistic change found in the data should be considered normal or abnormal.

People who trace their descent to Kazukuru speakers are linked to the Kazukuru tribe of the Roviana-speaking peoples of the Roviana Lagoon, on the southern coast of the island of New Georgia in the Solomon Islands. The Kazukuru and the Roviana were originally separate groups inhabiting the inland of New Georgia. In the inland west of New Georgia some 400 to 500 years ago there was a merger of the Kazukuru and Roviana peoples, and the group expanded south to the Roviana Lagoon, where it assimilated or ousted the previous local groups. The development of the Kazukuru-Roviana polity in the Roviana Lagoon has been extensively studied in an archaeological and ethnographic framework that seeks to link archaeological objects to oral history (Aswani and Sheppard 2003). Oral histories from the Roviana Lagoon consistently refer to a process of migration from the inland (prominently featuring the "Bao" area, see figure I).

The Kazukuru-Roviana ancestors intermarried extensively in the period before their expansion to the coast, and there is archaeological confirmation (especially the shrine at Bao; Hall I964) of the claims from the earliest period treated by oral history that the Kazukuru-Roviana people were acting as a political unit even at this time. No primary cause for the close relations between Kazukuru and Roviana can be reconstructed. While a considerable amount is known about the formation of the Roviana-Kazukuru polity, the period that is most interesting from a linguistic perspective is the one immediately preceding this - that is, the period prior to the formation of the Kazukuru-Roviana polity, when the Kazukuru and the Roviana were not yet unified, and language presumably played its typical role in reinforcing group boundaries.

The movement of the Kazukuru and Roviana peoples toward the coast began from the sixteenth century. The Kazukuru-Roviana polity developed into a powerful and fairly centralized system of chiefdoms based around the Roviana lagoon and extending inland to include the ancestral Kazukuru-Roviana homeland. Some remnants of the Kazukuru people continued to live in the bush, although there was apparently a continual trickle of people moving down to the coast. About I50 years ago the last Kazukuru people resettled on the coast. There are some records suggesting that the remnant Kazukuru bush people were regarded with suspicion and/or derision by the earlier coastal settlers (Hall I964). However, there is no suggestion that during the earlier amalgamation of the Kazukuru and the Roviana there was any systematic social asymmetry between them that would determine the preservation of the Roviana language and the disappearance of Kazukuru. 
There are a number of possible explanations for the success of the Kazukuru-Roviana polity at the expense of the other people of the Roviana lagoon. The motivation for the foundation of the Kazukuru-Roviana polity is traditionally explained (i.e., in indigenous histories) as facilitating access to marine resources, in particular shell materials used in the production of shell money valuables. Symbolic valuables are more important in a centralized, stratified society, where they serve as a manipulable symbol of social power, so this traditional account supports the view that the geopolitical ascendancy of Kazukuru-Roviana was enabled by a new level of political organization (Aswani and Sheppard 2003). Population density in the interior was apparently very high — the current near depopulation of the interior follows a population crash in the late nineteenth century. Bayliss-Smith, Hviding, and Whitmore (2003) describe traces of an extensive taro-growing agricultural economy throughout inland New Georgia. They suggest (in commentary on Aswani and Sheppard 2003:S7I) that the food production of the inland Kazukuru-Roviana people was also an important element of their polity. However, the chronological sequence of shrine sites, with newer and more elaborate sites on the lagoon, suggests a shift in the cultural center of gravity even prior to the depopulation of the inland (Thomas, Sheppard, and Walter 200I:56I).

Pacification of the Solomon Islands (in particular the abolition of headhunting) was carried out by the British Navy in the late nineteenth century. Following this the Methodist Mission, founded in I902, carried out many of the functions of the administration and oversaw the economic integration of western New Georgia into a plantation-based economy (alongside a small group of resident European traders) (Bennett I987). By the I920s all the inhabitants of the hinterland had relocated to the coast. It seems likely that the Kazukuru language was kept alive within the Kazukuru-Roviana polity by the continuing geographic separation of at least some Kazukuru speakers, and that language shift

\section{FIGURE 1. THE KAZUKURU-ROVIANA POLITY WITH LINGUISTIC NEIGHBORS (LANGUAGE NAMES IN BOLD)}

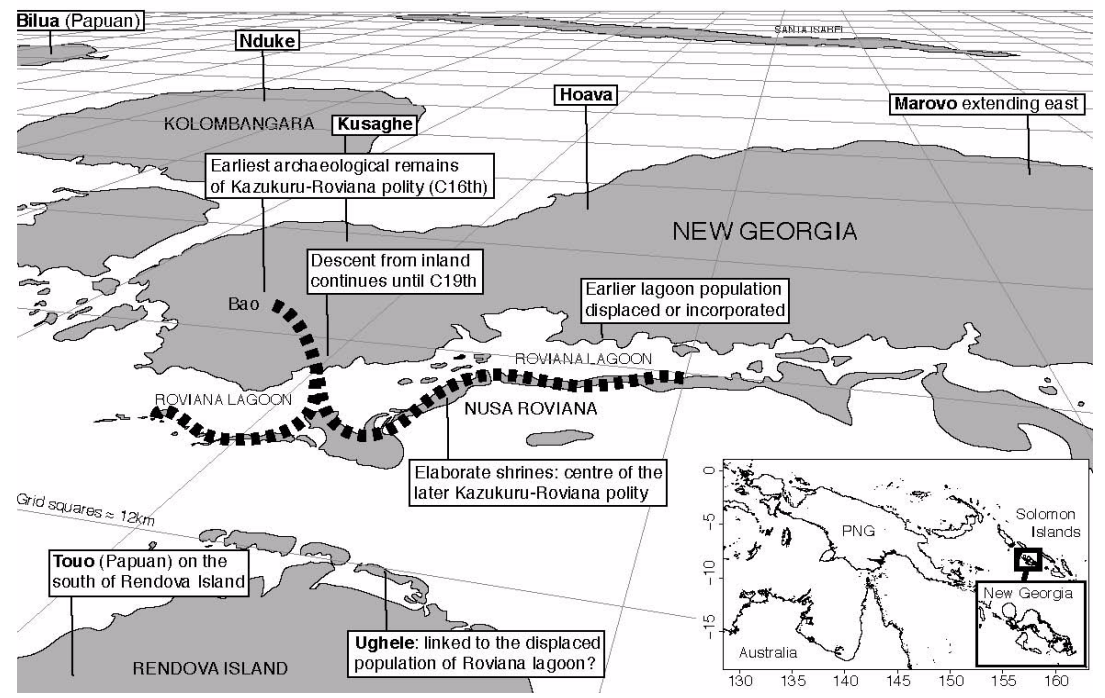


only moved into its final phase once all Kazukuru speakers were living within a Rovianalanguage community.

The story of the descent from the interior has a number of features that make it the natural beginning of the oral-historical sequence. The foundation and development of the Kazukuru-Roviana polity has itself been the main preoccupation of Kazukuru-Roviana people; the story of the unification of the peoples is culturally important, while details of the situation prior to unification do not contribute anything to the Kazukuru-Roviana understanding of the present (and it is likely that specialized historical traditions only arise in the presence of the relatively high level of political organization present in the Kazukuru-Roviana microstate; cf. Vansina I965:I70).

The Kazukuru language is unusual in that we only have knowledge of it from a period when it was one of two languages in use in a community. In the Solomon Islands an approximate correspondence between a linguistic group and an ethnic/culture group is the norm; one language may be used by several ethnic/culture groups, but it is unusual for there to be a single ethnic group with two languages not spoken elsewhere. The unusual state of affairs proved to be transitional, as the Kazukuru language was gradually replaced by Roviana.

3. LEXICAL COMPARISON. The Waterhouse and Ray (I93I) paper includes paradigms of pronouns and numerals, as well as a list of 209 Kazukuru lexemes. We reproduce this list in appendix I (beginning on page 230), together with our etymological and comparative observations. A number of the words in the list apparently reflect Oceanic forms. To demonstrate with reasonable likelihood that these are true reflexes (i.e., inherited forms, rather than loanwords) it would be necessary (i) to establish regular phonological correspondences, and ideally (ii) to show that among these correspondences are ones that are not present in languages that might have served as loan sources. However, given the fragmentary evidence available, this level of confirmation is not achievable.

What can be shown is that the number of Oceanic reflexes in Kazukuru has most likely been underestimated, and that they tend to be more obscure than in other New Georgia languages.

3.1 KAZUKURU WORDLIST. The wordlist in appendix I is from Waterhouse and Ray (I93I), but rendered in a broad IPA transcription instead of the orthography of the original (see 4.I). Similarities to forms in other Oceanic languages are noted. There are apparently more lookalikes than would arise by chance, and yet the relationship between the Kazukuru words and the lookalikes is not regular, and so we cannot impose a rigorous criterion for their inclusion or exclusion from this list. ${ }^{2}$

The list contains what seems to be a significantly large number of words beginning with the sequence Cin-. The mean number of instances of any given three segment sequence at the beginning of a word is approximately 3 and the median value is I, yet there are 45 words beginning with Cin-. (The next most frequent word beginnings after Cin- are Cit- $(\mathrm{n}=\mathrm{I} 4)$ and $\mathrm{Cil}$ - $(\mathrm{n}=\mathrm{IO})$.) An anonymous reviewer wonders whether some of these reflect the nominalizing infix <in $>$, also reflected in Roviana and its close relatives. However, to recognize such a nominalization entails (i) that the word be a noun and

2. Abbreviations used in the wordlist and elsewhere in this article are Rov. for Roviana and POC for Proto-Oceanic. 
(ii) that the root verb also occur on the list or be recognizable through its cognacy with a verb root that occurs in other Oceanic languages. No word beginning with $\mathrm{Cin}$ - fulfills these conditions, and a number of words with $\mathrm{Cin}$ - are not nouns. Thus we can only note the phenomenon, but not explain it.

We need to maintain a critical stance about the quality of the wordlists in Waterhouse and Ray (I93I), because we do not know how fluent the Kazukuru speakers were who produced the wordlists in the first place. We do know that they had married into (Roviana-speaking) Munda families, and Waterhouse reports that at the time of collection the language was not in daily use. It is also possible that the list is selective, biased toward words that are saliently dissimilar to Roviana. We can derive some confidence in the quality of Ray's communication and of Waterhouse's observation from Waterhouse and Ray (I927), which gives information about the Baniata (properly "Touo") language of Rendova. The transcriptions miss some subtleties of the phonological system (nonmodal vowels, and the existence of contrasting $o$ and $\rho$, but are otherwise excellent). However, we must also be alert to the possibility that the data preserved in the wordlist are mixed with Roviana or other languages of Western Province, or that they are confused with other linguistic remembrances.

3.2 COGNATE COUNTING AND LEXICAL DISTANCE. Western Oceanic languages from the Solomons are known to be lexically innovative (Tryon and Hackman I983; see also table 5), so we would not necessarily expect a high level of cognacy even if Kazukuru were an Oceanic language. Furthermore, the better attested Papuan languages of the Solomon Islands have quite high rates of Oceanic loanwords. The result is that we cannot make strong predictions about the affiliation of Kazukuru on the basis of counts of putative cognates.

Tryon and Hackman (I983) include the Waterhouse and Ray Kazukuru data in their lexical survey of the Solomon Islands. The comparative lists are accompanied by counts of putative cognates (i.e., lexicostatistical cognate percentage scores) for all the pairs of languages in the list. It is useful for our purposes that these counts were made independently, by scholars who were not testing the hypothesis that Kazukuru is Oceanic, because any confirmation bias in their cognate judgments would tend to minimize the number of Oceanic cognates. While we consider lexicostatistics unreliable as a method for uncovering linguistic relationships, lexical correspondence percentages do provide a similarity measure that can serve as a heuristic in genealogical hypothesis formation.

If we take the matrix of putative cognate percentages to be a rough measure of proximity between all the pairs of languages in the sample, then a tree showing the likely clusterings in the data (figure 2) gives us a heuristic for genealogical relationships among the languages. The measure of proximity was converted to a measure of distance by subtracting the cognate percentage in each cell from IOO (the resulting percentages are shown on the branches in the figure), and a tree was generated using the Neighbor-joining method (Saitou and Nei 1987, implemented by Swofford 2003; see also Felsenstein 2004:I6670; Gascuel and Steel 2006). The Neighbor-joining method starts from a completely unresolved tree (i.e., a star phylogeny) and cumulatively builds up clusters of nodes so as to minimize the total branch length of the tree (here representing lexical distance) at each 
step. The resulting tree (figure 2) accords well with known relationships. The Papuan varieties are all distant from each other (Baniata and Lokuru are communalects of Touo, not distinct languages), and are also distant from the Oceanic languages. The Oceanic languages subgroup neatly into a western New Georgia subgroup (Roviana, Hoava, Kusaghe, and Ughele), an eastern New Georgia subgroup (Marovo, Bareke, and Vangunu), and a subgroup for the islands to the west of New Georgia (Nduke, Simbo, Lungga, and Ghanongga). Kazukuru is positioned on this tree outside these Oceanic clades, but nearer to them than to any of the Papuan languages.

3.3 VARIETIES: KAZUKURU, GULIGULI, AND DORORO. The linguistic record of Kazukuru and its putative sister languages consists of a mere 209 words of Kazukuru proper, 36 words of Guliguli, and 2 I words of Dororo.

The Lanyon-Orgill wordlists for Guliguli and Dororo present a quandary to historical linguists. There are serious concerns about the quality of some of Lanyon-Orgill's publications, including evidence in some cases of outright fabrication (see Lanyon-Orgill I979; Geraghty I983), or apparent plagiarism (Lanyon-Orgill I955; Teeter I958). While this somewhat undermines the confidence we can have in his data, most of his earlier published wordlists seem to be legitimately compiled from manuscript sources, ${ }^{3}$ even when his own contribution to the collection of primary sources is exaggerated. Table I com-

\section{FIGURE 2. NEIGHBOR-JOINING TREE OF LEXICOSTATISTICAL DATA FROM WESTERN SOLOMON ISLANDS LANGUAGES*}

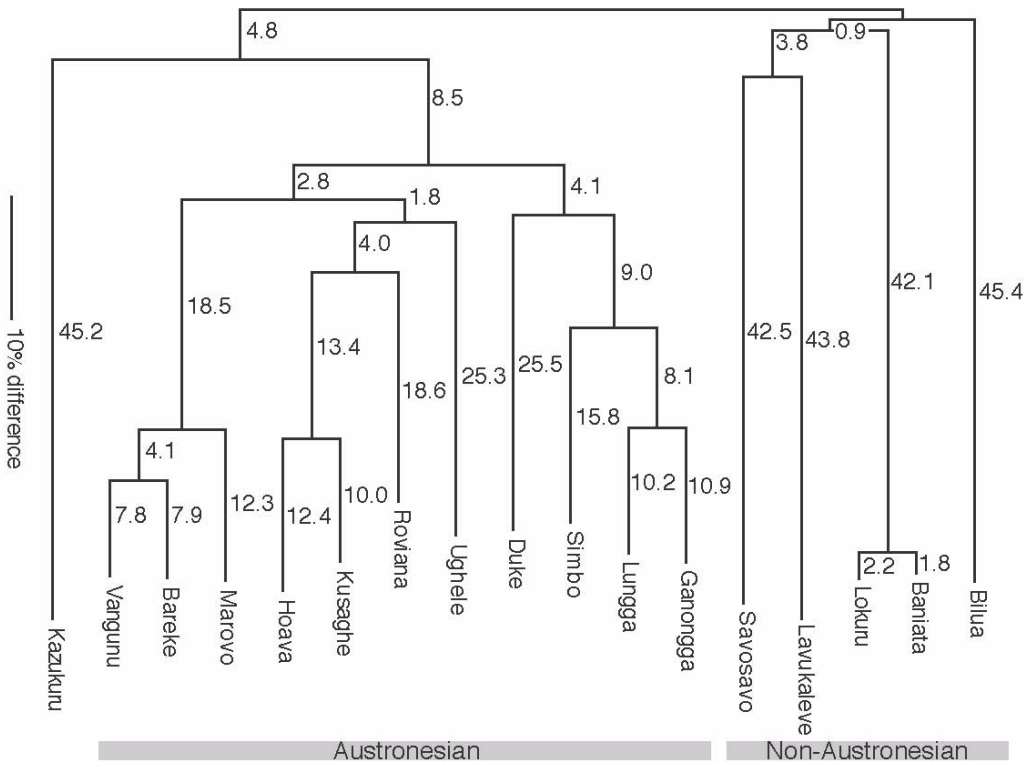

* From Tryon and Hackman (I983). Lexical distance (calculated from apparent cognate percentage) makes a clear split between Oceanic and Papuan, with Kazukuru intermediate.

3. See, for example, Lanyon-Orgill ( I960), a notice in Current Anthropology seeking manuscripts of Pacific island linguistic materials. 
pares Lanyon-Orgill's wordlists 4 of Guliguli and Dororo with the corresponding Kazukuru forms from Waterhouse and Ray. The geographic specification given in footnote 4 is unclear. Kazukuru was spoken on parts of Mt. Vinaroni, particularly on its western side, which suggests that Guliguli may be geographically coincident with Kazukuru. But there are no other records of Papuan languages being spoken on its eastern side; the attribution of the Guliguli to the "other side" of Mt. Vinaroni may simply be a mistake.

The case for Dororo and Guliguli being separate languages — or even separate dialects - from Kazukuru is weak. There are 32 Guliguli forms and I9 Dororo forms in the list (not counting doubled forms, such as Dororo mata, meta 'eye'). Of the Guliguli terms, 30 out of 32 ( 94 percent) are clearly cognate with Kazukuru terms; for Dororo the numbers are I5 out of I9 ( 79 percent). Even identical lists of lexical prompts should not be expected to produce identical responses from two different speakers of the same language (Reesink

\section{TABLE 1. WORDLISTS OF KAZUKURU, GULIGULI, AND DORORO*}

\begin{tabular}{|c|c|c|c|}
\hline & KAZUKURU & GULIGULI & DORORO \\
\hline 'arrow' & pito & bito & bito \\
\hline 'ax' & taunona & tajona & tinoni \\
\hline 'banana' & vinovo & vino & bino \\
\hline 'belly' & lea & lia & - \\
\hline 'blood' & rinati & linati & - \\
\hline 'body' & viniti & vini & vinitini \\
\hline 'bowels' & $\operatorname{sinu}$ & sinunu & - \\
\hline 'butterfly' & pilapila & bilabila & pepe \\
\hline 'cloud' & hinu & $\sin u$ & sinua \\
\hline 'crocodile' & bina bina & bina & bina \\
\hline 'die' & minata & minate & mate, minate \\
\hline 'ear' & ninoia & taninoia & nayinoa \\
\hline 'eye' & meta & mata & mata, meta \\
\hline 'father' & mamato & mama & mamamama \\
\hline 'fish' & mesai & mesa & - \\
\hline 'fly (N)' & zinojo & zinono, zinoni & - \\
\hline 'hand' & vonili & voniri & rimi \\
\hline 'head' & rano & rano & rano \\
\hline 'house' & valou & vale & pale \\
\hline 'leg' & nukolou & nokolou & - \\
\hline 'lip' & mono & mono & - \\
\hline 'moon' & retulu & retulo & - \\
\hline 'mouth' & noyano & jonano & jonano \\
\hline 'night' & muni & moni & moni, muni \\
\hline 'nose' & sunu & susuyu & - \\
\hline 'pig' & purono & burono & - \\
\hline 'stone' & pitoni & bito, bitono & - \\
\hline 'sugarcane' & mizamiza & mesamesa & mesa \\
\hline 'tongue' & lepani & lebani & - \\
\hline 'tooth' & titio & tititio & - \\
\hline 'water' & kiloni & kino, kiju & ju \\
\hline 'wind' & imeime & mememei & - \\
\hline 'yam' & minono & miminono & - \\
\hline
\end{tabular}

After Waterhouse and Ray (I93I) and Lanyon-Orgill (I953).

4. "The first of these word-lists is in a dialect called Guliguli, spoken on the western slopes of Mt. Vina Roni, and was sent to me by Mr. Houston, it having been compiled from some unnamed native. The second is of Dororo, spoken on the other side of Mt. Vina Roni, but having much in common with Guliguli" (Lanyon-Orgill I953:I25). 
I976 estimates 20 percent unreliability in "first" wordlists). Furthermore, the vagaries of ad hoc transcription systems, especially when we know there has been more than one generation of copying, seem sufficient to account for the formal differences between the ostensible cognates. There is a systematic merger of Kazukuru $p$ and $b$ as $b$ in Guliguli, which might be considered counterevidence to this possibility, but which is equally likely to be an artifact of transcription. The most parsimonious account of the Guliguli and Dororo data is that they are both transcription variants of Kazukuru, rather than distinct dialects.

Davis (2003:I5) has discovered no memory of languages called Dororo or Guliguli among the Hoava-Kusaghe speakers she worked with (on the northwestern coast of New Georgia). She expresses skepticism about the existence of these languages. She notes that guliguli is Hoava for 'masturbate', which may be evidence that this language is a hoax. Davis also discusses two other alleged extinct languages of New Georgia, concluding that they might be memories of a generated "secret language" based on metathesis (Davis 2003:28). While we think it is clear that the Kazukuru language did exist, some of the forms quoted as Kazukuru may actually be forms from such secret languages, that is, intentionally obscured forms from Roviana, Hoava, or Kusaghe. Kazukuru certainly contains a number of forms that look like metathesized Oceanic, and metathesis is not uncommon in other, "normal," Oceanic languages of the Solomons.

The formal similarities between the terms in these two wordlists and Kazukuru suggest to us the level of similarity expected in different naive transcriptions of the same source language. Some of the variation between the lists is particularly suggestive: ninoia, taninoia, and naninoa (all 'ear') look like a single form, with prefixes on Guliguli and Dororo that might be dialect variants or might be different prefixes.

4. STRUCTURAL COMPARISON. Only a very small amount of evidence of the structure of Kazukuru has survived. There are free and possessive pronoun paradigms, and a couple of two- and three-word phrases (including two apparent prepositions). The structural characteristics of Kazukuru that can be reconstructed from the available data are consistent with an Oceanic language.

There are typological features that can be considered typical of the extant Papuan languages of the central Solomons (Bilua, Touo, Lavukaleve, Savosavo; see Dunn, Reesink, and Terrill 2002). Even if the living Papuan languages of the Solomons form a single genealogical group, it does not follow that any other Papuan language should also be a member of this group. Nevertheless, any similarities that Kazukuru has to members of this group would be particularly suggestive. In 4.4 we discuss, and ultimately dismiss, the suggestion by Capell (1969) that Kazukuru has noun classes.

4.1 PHONOLOGY. Throughout this paper all vernacular forms have been standardized to broad IPA transcription. The consonant graphemes used in the Kazukuru wordlist are shown in table 2. They are derived from the Roviana orthography, a writing system introduced by the Methodist Mission, which was in its turn derived from the orthography developed by the mission in Fiji (discussed in Terrill and Dunn 2003). This system uses "q" for " $g$, which implies that "g" is used, as in Roviana, for $\gamma$. However, the Roviana system does not use digraphs, whereas the Kazukuru wordlist has "mb" for intervocalic

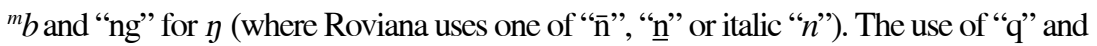


intervocalic "mb" implies that voiced stops were prenasalized, as in Roviana, at least intervocalically. In our transcription we write $b, d$, and $g$.

If the graphemes in table 2 correspond to phonological contrasts, then the Kazukuru phonological system has a structure identical to that of Roviana and Hoava. The vowels are likewise identical, a five-vowel system with $i, e, a, o, u$ (as noted, however, in 3.3, Waterhouse and Ray [1927] missed the areally unusual $o-o$ contrast in Touo). Syllables can all be accounted for by a $(\mathrm{C}) \mathrm{V}$ structure - there are a few examples of sequences that might be diphthongs, such as $\mathrm{CV}_{\mathrm{I}} \mathrm{V}_{2}$, and one apparent consonant sequence in vutlono 'tree'.

The $r-l$ distinction is mildly notable, in that most Oceanic languages have this distinction, whereas approximately half the Papuan languages of island Melanesia do not. There is, however, only one word in the list with both $r$ and $l$ (retulu 'moon'), so we must allow for the possibility that the $r-l$ distinction is allophonic variation or a transcriber artifact.

4.2 PRONOUNS. The Kazukuru pronouns are similar to the pronouns of the surrounding Oceanic languages, both in their forms and in the structural principles of the paradigms. If we accept these pronouns as correct, inherited forms, they must be taken as clear evidence that Kazukuru is closely related to the other Oceanic languages of New Georgia. To maintain this claim, an explanation must be found for the divergence of the rest of the Kazukuru lexicon. The alternative hypothesis is that the pronouns might be borrowings from the neighboring languages - either well-established loans or loans made during the process of language death.

Table 3 gives the free pronouns of Kazukuru along with those of Hoava, Roviana, and Ghanongga, as well as the relevant reconstructed Proto-Oceanic (POc) forms from Lynch, Ross, and Crowley (2002:67-68). Other variant forms are also reconstructable, but the forms given in table 3 are those reflected in the languages of the New Georgia group. Sources of Roviana, Ghanongga, and Hoava forms are respectively Ross (I988), Kettle (2000), and Davis (2003).

The basic similarity of the Kazukuru forms to the other New Georgia forms in table 3 is self-evident, and from these forms we can make further observations about probable subgrouping within Oceanic. The Oceanic subgroups relevant to this discussion are set out in (I) (Lynch, Ross, and Crowley 2002:IOI-2). ${ }^{5}$ Labels in Roman are subgroups; a label in italics indicates that the member languages do not necessarily form a single subgroup.

\section{TABLE 2. GRAPHEMES USED BY WATERHOUSE AND RAY (1931) IN THEIR KAZUKURU TRANSCRIPTION}

$\begin{array}{lccccc} & & \text { BILABIAL } & \text { ALVEOLAR } & \text { VELAR } & \text { GLOTTAL } \\ \text { STOP } & \text { [+voice] } & \mathrm{b}, \mathrm{mb} & \mathrm{d} & \mathrm{q} \text { (for g) } \\ & \text { [-voice] } & \mathrm{p} & \mathrm{t} & \mathrm{k} & \mathrm{ng}(\text { for } \mathrm{j}) \\ \text { NASAL } & & \mathrm{m} & \mathrm{n} & \mathrm{g}(\text { for } \mathrm{\gamma}) & \mathrm{h} \\ \text { FRICATIVE } & \text { [+voice] } & \mathrm{v} & \mathrm{z} & \\ & \text { [-voice] } & & \mathrm{s} & \\ \text { LATERAL } & & \mathrm{r} & \end{array}$

5. The arguments for these groupings are found in Ross (I988), those for the Northwest Solomonic linkage and its subgroups in chap. 7. 
(I) Oceanic

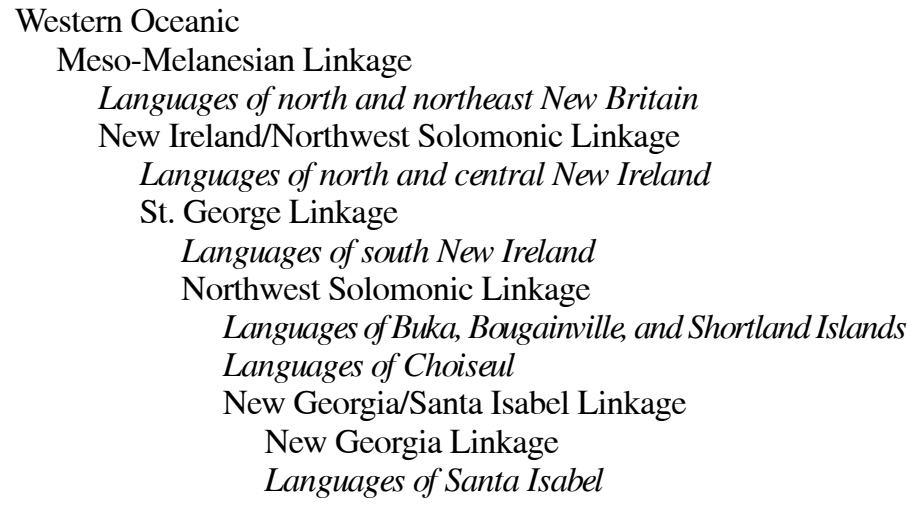

One of the innovations that characterizes the Western Oceanic group is the replacement of POC *ira FREE:3PL (the free pronoun) by the form *idri[a]. In the languages of Choiseul, New Georgia, and Santa Isabel, however, the reflected form is *iri[a] rather than *idri[a]. This apparent innovation is perhaps evidence for a subgroup that was not recognized by Ross (I988). However, this will not be pursued here. ${ }^{6}$ What is important is that the FREE:3PL forms in table 3 all appear to reflect *iri[a], implying that Kazukuru forms a subgroup with its neighbors.

A feature of Northwest Solomonic languages is that their non-3rd-person free pronouns often reflect a sequence ARTICLE- $r$-PRONOUN, where $-r$ - is an old ligature dating back to a time when the St. George Linkage was a unity (Ross I988:247-48). For example, in Varisi (Choiseul) we find $e-r$ - $a$ FREE: ISG, $a$ - $r$ - FREE:2SG, $r$-emu FREE:IPL.EXCL, $r$-ати FREE:2PL (the article is lost from the disyllabic plural forms). In the languages of New Georgia and Santa Isabel, however, such forms are found only in FREE: ISG pronouns, as in Roviana $a$-r-au, Ghanongga $a-r-a$, and Hoava $a-r$-ao. No reflex of *-r- occurs in non-ISG forms. ${ }^{7}$ It is notable that the Kazukuru pronouns also pattern in this way. To be

TABLE 3. FREE PRONOUNS

\section{IN KAZUKURU, HOAVA, ROVIANA, AND GHANONGGA}

\begin{tabular}{|c|c|c|c|c|c|}
\hline & POC & KAZUKURU & HOAVA & ROVIANA & GHANONGGA \\
\hline ISG & *au & rauno & rao & arau & ara \\
\hline $2 S G$ & $* \mathrm{ko}[\mathrm{e}]$ & yoino & yoe & ayoi & ao \\
\hline $3 \mathrm{SG}$ & $*_{\text {ia }}$ & sana & (i)sa & asa & aza \\
\hline I PL.INCL & *kita & gito & yita & yita & yita \\
\hline IPL.EXCL & *kami & yimo & yami & yami & yami \\
\hline $2 \mathrm{PL}$ & *kamu & jumo & yamu & yamu & yamu \\
\hline 3PL & *ira & riniai & ria & arini & ria \\
\hline
\end{tabular}

6. The situation is further complicated by the fact that FREE:3SG forms in certain Northwest Solomonic languages, namely Vaghua (Choiseul) ora, Sisingga (Choiseul) ara, Lungga (New Georgia) ira, and Laghu (Santa Isabel) zara, appear to reflect POc *ira rather than PWOc *idri[a]. While we have no explanation for this, it does not affect the argument here.

7. It is tempting to formulate this conclusion more sharply, and to say that loss of *-r- in non-ISG forms is an innovation that defines the New Georgia/Santa Isabel linkage. However, there are non-ISG forms without *-r- scattered across the Northwest Solomonic linkage, so we are reluctant to claim this as an innovation that is significant for subgrouping. 
sure, the singular forms appear to have lost their initial syllable - $a$ - in the other languages in table 3-and have acquired a final $-n \mathrm{~V}$, but it seems inescapable that the Kazukuru paradigm has the same origins as the Ghanongga, Roviana, and Hoava forms.

Kazukuru gimo FREE:I I L.EXCL ( $<*$ kami) and gumo FREE:2PL ( $<*$ kamu) entail (i) vowel metathesis and (ii) a fairly widespread but not regular change $*_{\mathrm{a}}>0 .{ }^{8}$ It is worth noting, incidentally, that these forms associate Kazukuru more closely with the New Georgia languages than with those of Santa Isabel, where plurals lack*-m-, as in Kokota gai and gau (this is probably not a Santa Isabel innovation but a retention of the alternant POc forms *kai and *kau).

Waterhouse and Ray (I93I) also provide a paradigm of "possessive pronouns." In Roviana and Hoava, as in many Oceanic languages, there are direct and indirect possession constructions (Lichtenberk 1985), encoding inalienable and alienable possession, respectively. In the direct construction, a possessor pronoun suffix is attached directly to the possessed noun (e.g., Roviana tama-gu 'my father'). In the indirect construction, a possessor pronoun suffix is attached to a possessive "classifier" (a language typically has I-3 classifiers, but some have more), and the classifier-suffix combination either precedes or follows the possessed noun. Waterhouse and Ray (I93I) provide no data relevant to direct possession and just two apparent instances of indirect possession. One is Kazukuru anu-mami solu CLASS-IPL.EXCL house, 'our (EXCL) houses', where -mami reflects the POC suffix *-ma[m]i POSS: IPL.EXCL and is identical to the corresponding Roviana and Hoava direct possessor suffix. ${ }^{9}$ What is interesting is that the classifier-suffix combination in Roviana and Hoava has undergone attrition to form possessive pronouns that are no longer segmentable into two morphemes (e.g., Roviana mami vetu 'our (EXCL) houses'. The Kazukuru form anu-, however, seems to be cognate with a classifier of the same form found in languages of south New Ireland (Label, Bilur, Kandas, Siar), suggesting that in this regard Kazukuru was more conservative than its New Georgia neighbors. This is evidence that the paradigm is not a wholesale borrowing - although it is, of course, possible that the paradigm was borrowed by Kazukuru from a language no longer present in the region, the hypothesis that this conservative feature is a true retention from the ancestral form may be preferred as a more parsimonious account of the data.

The "possessive pronouns" given by Waterhouse and Ray ( I93 I represent the prepositional possession type, one of three forms of possession found in New Georgia languages (evidently all descending from Proto-Oceanic). The Kazukuru, Roviana, and Hoava prepositional possession forms are given in table 4. Of the two columns showing POC reconstructions, the first shows the reconstructed possessor suffixes and the second repeats the free pronouns from (3).

Roviana vetu ta-mi-yami is an alternative encoding of 'our (EXCL) houses', where the postnominal word consists of the preposition ta-, the possessor suffix - mi (a reduced form of the direct possessor suffix -mami POSS: IPL.EXCL), and the free pronoun yami. The Hoava forms can be similarly segmented, and Davis considers the free pronouns still to form separate words. The Kazukuru forms appear to be compound forms like those in

\footnotetext{
8. Also seen in rinotu 'child', vedorou 'club', emo 'come', gito FrEE: IPL.INCL, limoni 'five', and in the apparent 3 SG possessor suffix $-n o$ (<POC - $\tilde{a} a$ 'her/his': see end of this section).

9. The other instance occurs in moloto qonu 'my lying down', where qonu is presumably the possessive, but we are unable to analyze it further.
} 
Roviana. The form tiu- is perhaps cognate with Roviana and Hoava ta-. Given that these are clearly compound forms, a good deal of analogical change must have occurred, with (it seems) - de- POSS:IPL.INCL (< POC *-da) and POSS:3PL (<POC *-dri[a]) expanding to the other two plural forms and into 3SG (cf. Roviana and Hoava). There is reasonably good formal evidence, however, that these forms could have arisen from earlier combinations like those in Roviana and Hoava. ${ }^{10} \mathrm{We}$ can also conclude that while the Kazukuru paradigm is related to that of the other Oceanic languages of New Georgia, the paradigm is not borrowed directly from any surviving language.

It is possible that the Oceanic direct possession construction is also represented in the data in the shape of what in other Oceanic languages would be inalienably possessed body-part nouns. A number of these (and a kinship noun) end in -no, which may reflect the Proto-Oceanic suffix *-ña 'her/his': suno 'breast' (< POC *susu-ña), neuno 'foot', rano 'head', mono 'lip', nonano 'mouth', mamano 'mother'. We cannot be certain about this, however, as other nouns whose semantics would invite inalienable possession lack final -no, for example, lea 'belly', rinati 'blood', rinotu 'child', ninoia 'ear'.

4.3 NUMERALS. Kazukuru numerals share a number of lexical similarities with the neighboring Oceanic languages. They are base ten, in common with all the Oceanic and Papuan languages of the area. There are also signicant differences that are difficult to explain. In particular, the teens (I I-I9) are quite irregular (as noticed by Waterhouse and Ray I93I:I24); the multiples of ten are less regular than in other languages of the Central Solomons. ${ }^{\text {II }}$

Table 5 lists the numerals from I to Io in Proto-Oceanic (Lynch, Ross, and Crowley 2002:72) and the three Oceanic languages. Bolded forms are taken to reflect Proto-Oceanic forms. Roviana and Hoava forms are identical except for ' 3 '. In view of the rather different Ghanongga set, this may likely be attributed to borrowing by Hoava from Roviana, as Roviana is the areal lingua franca.

The Roviana, Ghanongga, and Hoava numeral sets are clearly more similar to each other than any of them is to the Kazukuru set. What is signicant here, however, is that Roviana, Ghanongga, and Hoava each reflects only five or six of the ten Proto-Oceanic forms while Kazukuru reflects four. This is typical of the lexicons of New Georgia lan-

\section{TABLE 4. POSSESSIVE PRONOUNS IN KAZUKURU, ROVIANA, AND HOAVA}

\begin{tabular}{|c|c|c|c|c|c|}
\hline & POC & & KAZUKURU & ROVIANA & HOAVA \\
\hline ISG & $*_{-g u}$ & $* \mathrm{au}$ & rinatau & ta-q-arau & ta-qu arao \\
\hline $2 \mathrm{SG}$ & $*$-mu & $*^{*} \mathrm{ko}[\mathrm{e}]$ & tiu-mu--уо & ta-mu-yoi & ta-mu ayoe \\
\hline $3 \mathrm{SG}$ & *-ña & $*$ ia & tiu-deni-si & ta-ni-sa & ta-ni isa \\
\hline IPL.INCL & $*_{\text {-da }}$ & *kita & tiu-de-yuto & ta-di-yita & ta-di yita \\
\hline IPL.EXCL & $*_{-m a[m] i}$ & *kami & tiu-do-yino & ta-mi-yami & ta-mi yami \\
\hline $2 \mathrm{PL}$ & $*_{-m}[\mathrm{i}] \mathrm{u}$ & *kamu & tiu-de-yoni & ta-mu-yamu & ta-mu yamu \\
\hline 3PL & $*$-dra & *ira & tiu-de-ore-no & ta-di-rini & ta-di ria \\
\hline
\end{tabular}

IO. We are tempted to surmise that rinatau ISG is a misprint for tinarau, which would then also include the free form rau-.

I I. The nearest non-base-ten counting systems are found in the Papuan languages of Bougainville - these are considerably less elaborate than the counting systems of any of the Oceanic languages of the Solomons, and are entirely unlike the Kazukuru numerals with regard to both lexical form and structural principles. 
guages (other than Kazukuru, for which we have scant lexical data). They are phonologically conservative, so that Oceanic items are easily recognized, but they are lexically innovative. Even basic vocabulary items are quite likely not to have cognates outside New Georgia. This suggests there was once substantial borrowing from one or more Papuan languages, although this cannot be known with certainty (Evans forthcoming).

Kazukuru numerals above Io, shown in table 6, are intriguing. We would expect to see some kind of pattern connecting the numerals from I to 9, those from I I to I9, and the tens from Io to 90, but there are fewer connections than we would expect, and they are irregular. (This is not true of the Roviana numerals, where those from I2 to I9 are maneje rua, and so on, and those from 30 to 90 are tolu yavulu, and so on; see table 7.)

TABLE 5. THE NUMERALS 1-10 IN NEW GEORGIA

\begin{tabular}{|c|c|c|c|c|c|}
\hline & POC & KAZUKURU & ROVIANA & GHANONGGA & HOAVA \\
\hline I & *tasa, *sakai, *tai, *kai & nasata & tasa, keke & ma-za & keke \\
\hline 2 & $*$ rua & runa-runa & ka-rua & ko-ri & ka-rua \\
\hline 3 & $*$ tolu & taniro & yeta & kue & hike \\
\hline 4 & *pat[i] & dinoe & made & ka-made & made \\
\hline 5 & *lima & limoni & lima & ka-lima & lima \\
\hline 6 & *onom & pinopo & onomo & vonomo & onomo \\
\hline 7 & *pitu & sineva & zuapa & ka-vitu & zuapa \\
\hline 8 & *walu & sulasu & vesu & ka-vesu & vesu \\
\hline 9 & *siwa & lusi & sia & sia & sia \\
\hline IO & $*_{\text {sa[-na]-puluq }}$ & genole & manege & manoga & manege \\
\hline
\end{tabular}

TABLE 6. STRUCTURE OF THE KAZUKURU COUNTING SYSTEM

\begin{tabular}{|c|c|c|c|c|c|c|}
\hline & \multirow[t]{2}{*}{ POC } & \multicolumn{5}{|l|}{ KAZUKURU } \\
\hline & & UNITS & & TEENS & & DECADES \\
\hline I & *tasa, *sakai, *tai, *kai & nasata & I I & genege & IO & genole \\
\hline 2 & $*$ rua & runa-runa & I 2 & runi-to & 20 & zamanonu \\
\hline 3 & $*$ tolu & taniro & I3 & ginata & 30 & tolu-to \\
\hline 4 & *pat[i] & dinoe & I4 & dinoe-va & 40 & mido-no \\
\hline 5 & *lima & limoni & I 5 & yonayo & 50 & milo-no \\
\hline 6 & *onom & pinopo & I6 & piloene & 60 & ulo-no \\
\hline 7 & *pitu & sineva & 17 & sineva-ri & 70 & zito-no \\
\hline 8 & *walu & sulasu & I 8 & sula-no & 80 & viso-no \\
\hline 9 & *siwa & lusi & I9 & lise-ne & 90 & sinoto \\
\hline
\end{tabular}

TABLE 7. STRUCTURE OF THE ROVIANA COUNTING SYSTEM

$\begin{array}{ll} & \text { UNITS } \\ \text { I } & \text { tasa } \\ 2 & \text { ka-rua } \\ 3 & \text { jeta } \\ 4 & \text { made } \\ 5 & \text { lima } \\ 6 & \text { onomo } \\ 7 & \text { zuapa } \\ 8 & \text { vesu } \\ 9 & \text { sia }\end{array}$

TEENS
maneye eke
maneye rua
maneye yeta
maneye made
maneye lima
maneye onomo
maneye zuapa
maneye vesu
maneye sia

TENS

Io maneye

20 hiokona puta

30 tolo yavulu

40 made yavulu puta

50 lima yavulu puta

60 onomo yavulu

70 zuapa yavulu puta

80 vesu yavulu

90 sia yavulu

Ioo keke goyoto 
Note that the relative sophistication of the counting system does not require any special explanation. There is evidence from oral history that in the period prior to European contact, the peoples of New Georgia engaged in a number of competitive activities that required counting. Keeping score of headhunting victims was probably one of these (with counts apparently going above IOO for successful headhunters), but another more ancient activity (requiring numbers into the thousands) was competitive taro growing.

4.4 NOUN CLASSES? Capell (I969) suggests that the Kazukuru data might show evidence of noun classes. The Papuan languages of Island Melanesia almost all have some system of nominal classification or another, and this feature more than any other contributes to the belief or suspicion on the part of many linguists that the Island Melanesian Papuan languages must form a family. While noun classes are present in some Oceanic languages, they can be shown to be recent innovations; none of the Oceanic languages in the immediate neighborhood of Kazukuru has noun classes. Presence of noun classes in Kazukuru could indicate a non-Oceanic substrate. Capell claims that this evidence is at least suggestive, but we will argue that available evidence of noun classes is too meager to base any conclusions on. The possible noun classes proposed by Capell are listed and evaluated below (Capell I969: I ). Capell has fourteen classes, apparently based on his acquaintance with other Papuan languages where each class is marked by a suffix, but he gives semantic labels to only four of them, and we list these first. He considers the endings $-i,-o$, and $-u$ to be the most doubtful candidates for identication as classes. In each case we list the membership of the proposed class, and count how many of the likely nouns in the wordlist have this pattern compared to the total number of forms matching the pattern (numerals are not included in either count, because it is not clear whether or not they should be treated as nouns).

-i Capell notes that these are "all vegetable products." Once probable verbs, pronouns, and numerals are excluded, as well as items ending in -ni, - $n i,-r i$, $-s i$, or - $t i$, treated separately by Capell, Io forms remain. Only four ('basket', 'mat', 'vine', 'leaf') are vegetable products.

sukinai 'basket', huhumi 'darkness', mesai 'sh', sinimai 'esh', sininai 'food', vonili 'hand', piloi 'leaf', hamihami 'mat', avi 'paddle', seroi 'vine, creeper'

Only I I words in all fit this phonological pattern-and Io are nouns, so it is not implausible that final $-i$ is some kind of morpheme.

-u Capell identifies six terms, with the note "some wooden or wooded objects and body parts." The wordlist has 33 such forms, of which 17 are nouns (excluding - $t u$ forms, treated separately by Capell), and of which five ('basket', 'club', 'forest, bush', 'house', 'spear') are wooden or have wooden parts.

sukonou, sukinai 'basket', piku 'betel (areca) nut', kinoukorurenou 'bird', sinu 'bowels', hinu 'cloud', vedorou 'club', renou 'creek', ginutu-reukenu 'feather', rinurinu 'finger', butu vulu 'forest, bush', valou 'house', retulu 'moon', nigou 'neck', supu 'nose', mekuhu 'rain', zatobau 'spear', zinou Kazukuru 'Kazukuru language'

-na Capell notes "mostly living beings"; Io forms out of ${ }_{5} 5$ in the wordlist are nouns, but only 'husband' and 'possum' denote living beings.

taunona 'axe', runa 'breadfruit', voarana 'coconut', kekeana 'daylight', ruvona 'flower', layasana 'husband', hinapouna 'possum', elopena 'sago palm', ukeana 'shell ornament', tabuna 'taboo' 
-ni Capell notes: 'objects and one or two body parts'; Io forms out of 17 in the wordlist are nouns, but 'name', 'night' (and arguably 'fire' and 'water') lie outside his definition:

hikani 're', memoni 'man', zeponi 'name', muni 'night', ritani 'road', pitoni 'stone', mekohoni 'taro', lepani 'tongue', kiloni 'water', siporoni 'wing'

Clearly the numbers above do not support Capell's suggestion that these are semantically based noun classes. Capell gives no semantic label to any of his ten other potential classes:

-o All forms except those with -no, -no, -ro, -to (treated below). There are I7 words in the wordlist fitting this pattern, of which four are nouns: vinovo 'banana', pilipuo 'dog', reo 'forehead', titio 'tooth' (Capell only gives pilipuo and zatobau 'spear', which he spells "zatobao").

-no I5 forms out of 22 in the wordlist are nouns. If suno 'breast' is of Oceanic origin (POC *susu), then -no may reflect the 3 SG possessor suffix on this and other inalienable nouns (4.2).

suno 'breast', searayano 'feast', neuno 'foot', rano 'head', mono 'lip', mamano 'mother', nonano 'mouth', sutuno 'musical instrument', virosino 'ornaments', purono 'pig', suporono 'pool', lovino 'shield', maninono 'taboo', vutlono 'tree', minono 'yam'

-ni The only example in the wordlist is a noun: sineni 'lime'

-no All three forms in the wordlist are nouns: vununo 'earth, soil'; linono 'egg'; zinono 'fly (n)' (Capell listed only the latter two).

-ri The only example in the wordlist is a noun: sinori 'bone'

-ro One of three forms in the wordlist is a noun: miroro 'hill'

-si One of three forms in the wordlist is a noun: siratisi 'river'

-ti Only two forms in the wordlist are nouns: rinati 'blood', viniti 'body'. Capell also includes the word metaleti 'death', which is not in any of the acknowledged sources.

-to Four of the eight forms in the wordlist are nouns. The most likely potential suffix is on mamato 'father', since mama occurs in Oceanic languages (and in the Papuan languages Touo and Savosavo). It is, however, a nursery form, making chance convergence much more likely. The other three nouns are unconvincing candidates for suffixation, being perhaps too short: pito 'arrow', rito 'belt', vato vato 'ground, land'.

-tu Two of the four forms in the wordlist, rinotu 'child' and ginutu 'hair', are nouns. (Capell mistranscribes ginutu as nginutu 'father'.)

The $-i$ ending is a possible candidate for a nominal suffix of some sort as Io out of I I words in $-i$ are nouns. While the items in each class are too few to evaluate statistically, there seems to be no tendency for the other endings to cooccur preferentially with nouns. In any case the high representation of nouns among $i$-final words doesn't necessarily lead us to infer noun class suffixation, or indeed, any kind of morphological process. It could be the result of historical accident.

A similar count of the frequencies of different phonological word endings has been carried out with a more extensive wordlist for Touo (Baniata), a language that does have noun class suffixes, to test whether this kind of statistical comparison could be expected to pick up the existence of the morphemes. But the results are inconclusive even there. The reason for this in Touo is that noun class endings appear inconsistently in citation forms - they are used with what is apparently an individuating or singulative function, and this function is not reliably elicited by a wordlist. 
The best evidence for suffixation is the handful of Oceanic cognates (be they loanwords, or inherited forms) with final syllables that cannot be accounted for. These include suno 'breast', mamano 'mother', mamato 'father', and tabuna 'tabu'. We have offered a tentative explanation of the first two above (4.2). The data are too meager to demonstrate conclusively that there is noun class morphology. Even though the other Papuan languages do have noun classes and noun class suffixes, the data we have for Kazukuru are insufficient to allow a firm conclusion either way.

\subsection{CONSTITUENT ORDER AND ADPOSITIONS}

Prepositional phrases. There is evidence that Kazukuru and Hoava have the same prepositional form and construction with the same meaning:

(2) KAZUKURU

mekuhu pa Kazukuru

(Waterhouse and Ray I93 I:I26, note I3)

rain PREP Kazukuru

'downpour approaching from Kazukuru'

(3) HOAVA

Sa binanara pa Daepaqo
ART:SG chieftainship PREP Daepanggo
'the chieftainship of Daepanggo'

(Davis 2003:96)

Davis notes that "prepositional phrases within noun-phrases usually refer to place names" (Davis 2003:96). This is also true of the Roviana locative. Note that it is possible to read (2) as a use of a Kazukuru word in a Roviana phrase rather than as an example of the Kazukuru language.

Another phrase is glossed only as "an expression re talo planting."

(4) payara na viyuviyu

(Waterhouse and Ray I93I:I25)

It is impossible to analyze this with certainty, as we have been unable to identify payara or vijuviju. The word na is plausibly a preposition, identical in syntax to a Roviana or Hoava preposition.

5. CONCLUSIONS. Sections $2-4$ have built up a synthesis of what is known about the sociolinguistic and typological profile of Kazukuru. The most salient features of this are (i) Kazukuru was a language of a single clan in a larger ethnic entity, the KazukuruRoviana polity, which had reoriented itself from the inland of New Georgia to the Roviana lagoon; (ii) the Kazukuru lexicon lies somewhere between the lexically divergent Oceanic languages of the western Solomons and the Oceanic-influenced Papuan languages of the Solomons; (iii) recoverable elements of the structure of Kazukuru are typical of an Oceanic language of the region (for example, the pronoun paradigms); and (iv) some mysteries, especially the complex numeral system, remain. In section I, four hypotheses were proposed to account for the difficulties in classifying Kazukuru. These will be assessed in turn to see how well they explain the observations.

Converged Papuan Language. A Papuan language that has converged with its Oceanic neighbors could be expected to acquire Oceanic syntax but to maintain its 
own morphology (Thurston I982). It might also—but need not—acquire Oceanic lexicon. To the extent that Kazukuru morphology is accessible to us, in particular the pronouns, its morphology is Oceanic, and Kazukuru is thus unlikely to be a converged Papuan language.

One might, of course, claim that Kazukuru is indeed a Papuan language and that it has borrowed its pronoun paradigms. Despite occasional claims to the contrary, however, the borrowing of whole pronoun paradigms in contact situations is exceedingly rare (Ross 2005:53-56). In any case, the forms of the Kazukuru paradigms, while clearly cognate, are too divergent from those of neighboring languages to be borrowed from one of them.

Mixed Language. Language mixing can be excluded as a most unlikely cause: currently attested mixed languages are created out of the needs of people with a culturally mixed origin to carve out a unique linguistic identity, distinct from the two source populations. The Kazukuru people do not conform to this type: the Kazukuru and Roviana tribes merged through marriage, and there is no evidence that any importance was attached to preserving or creating cultural distinctions between the two groups.

Rememberer variety. It is more plausible that Kazukuru is a linguistic chimera, fragments of a language elicited from rememberers at the last stages of language death. Some of the similarities between Kazukuru and Roviana are so marked (see, e.g., 4.5) that it suggests that many aspects of the original Kazukuru language may have already been lost at the time of recording. In such a case, it is possible that the remnants of Kazukuru that have been recorded contain syntactic improvizations (calqued on Roviana) to satisfy the demands of elicitation. Remembered lexicon may be biased in the other direction, toward lexicon that is saliently different from Roviana. In this case, the apparent lexical distance from the other New Georgia languages could be greatly exaggerated, even if the remembered variety was, in fact, originally Oceanic.

Oceanic. The hypothesis that Kazukuru was Oceanic does not exclude the possibility that it was also a rememberer variety as well. What we can see of Kazukuru structure (especially its pronoun paradigms) is similar to the other Oceanic languages of New Georgia, but notably not so similar that it can be readily interpreted as borrowing. The main divergence from the typical Oceanic languages of the area is its low percentage of cognate vocabulary, but the status and value of this evidence are ambiguous.

If there were no other Papuan languages in the Solomon Islands, is there anything about Kazukuru that would make us think that Kazukuru was not Oceanic Austronesian? On the basis of the available evidence, our answer is: probably not. While our judgment is a weighing up of probabilities, we conclude that reports that Kazukuru was a Papuan language have little foundation. Kazukuru was probably an Oceanic Austronesian language. 


\section{REFERENCES}

Aswani, Shankar. 2000. Changing identities: The ethnohistory of Roviana predatory head-hunting. Journal of the Polynesian Society I09:39-70.

Aswani, Shankar, and Peter Sheppard. 2003. The archaeology and ethnohistory of exchange in precolonial and colonial Roviana: Gifts, commodities, and inalienable possessions. Current Anthropology 44:S5I-78.

Bayliss-Smith, T., E. Hviding, and T. C. Whitmore. 2003. Rainforest composition and histories of disturbance in Solomon Islands. AMBIO: A Journal of the Human Environment 32:346-52.

Bennett, Judith A. 1987. Wealth of the Solomons. Honolulu: University of Hawai ' 1 Press.

Capell, Arthur. 1954. A linguistic survey of the South Western Pacfiic. Technical Paper No. 70. Noumea: South Pacific Commission.

- 1969. Non-Austronesian languages of the British Solomons. In Papers in the linguistics of Melanesia 2, I-I6. Canberra: Pacific Lingustics.

Davis, Karen. 2003. A grammar of the Hoava language, Western Solomons. Canberra: Pacific Linguistics.

Dunn, Michael, Ger Reesink, and Angela Terrill. 2002. The East Papuan languages: A preliminary typological appraisal. Oceanic Linguistics 4I:28-62.

Evans, Bethwyn. Forthcoming. The complementarity of genetic and contact relationships in linguistic prehistory: A pilot study from the Solomons.

Felsenstein, Joseph. 2004. Inferring phylogenies. Sunderlands, MA: Sinauer Associates.

François, Alexandre. 2006. Are Vanikoro languages really Austronesian? Paper presented at the 2nd Austronesian Languages and Lingusitics Conference (ALL2), Oxford, June 2-3.

Gascuel, Olivier, and Mike Steel. 2006. Neighbor-joining revealed. Molecular Biology and Evolution 23:1997-200I.

Geraghty, Paul. 1983. Review of Lanyon-Orgill, Captain Cook's South Sea Island vocabularies. Journal of the Polynesian Society 92:552-59.

Golovko, Evgenij. I994. Mednyj Aleut or Copper Island Aleut: An Aleut-Russian mixed language. In Mixed languages: 15 case studies in language intertwining, ed. by Peter Bakker and Maarten Mous, I I3-2 I. Studies in Language and Language Use No. I3. Amsterdam: Institute for Functional Research into Language and Language Use (IFOTT).

Hall, A. H. I964. Customs and culture from Kazukuru: Folklore obtained after discovery of the shrine at Bao. Oceania 35:I27-35.

Kettle, Eleanor. 2000. A description of the verb phrase in Ganoqa, an Austronesian language of the Solomon Islands. BA honours thesis, Australian National University.

Lanyon-Orgill, Peter A. I953. The Papuan languages of the New Georgian Archipelago, Solomon Islands. Journal of Austronesian Studies I: I 22-38.

- I955. An introduction to the Thai (Siamese) language for European students. Victoria, B.C.: Curlew Press.

- I960. Wanted. Current Anthopology i:257.

- I979. Captain Cook's South Sea Island vocabularies. London: published by the author.

Lichtenberk, Frantisek. 1985. Possessive constructions in Oceanic languages and in Proto-Oceanic. In Austronesian linguistics at the I5th Pacific Science Congress. Canberra: Pacific Linguistics.

Lincoln, Peter C. 1978. Reef-Santa Cruz as Austronesian. In Second International Conference on Austronesian Linguistics: Proceedings, ed. by S. A. Wurm and Lois Carrington, 929-67. Canberra: Pacific Linguistics. 
Lynch, John, Malcolm Ross, and Terry Crowley. 2002. The Oceanic languages. Richmond: Curzon.

Næss, Åshild. 2006.Bound nominal elements in Åiwoo (Reefs): A reappraisal of the "multiple noun class systems." Oceanic Linguistics 45:269-96.

Reesink, Ger. 1976. Languages of the Aramia river area. In Papers in New Guinea Linguistics, no. 19, I-37. Canberra: Pacific Linguistics.

Ross, Malcolm. 1988. Proto Oceanic and the Austronesian languages of Western Melanesia. Canberra: Pacific Linguistics.

. 2005. Pronouns as a preliminary diagnostic for grouping Papuan languages. In Papuan pasts: Cultural, linguistic and biological histories of Papuan speaking peoples, ed. by Andrew Pawley, Robert Attenborough, Jack Golson, and Robin Hide, I5-66. Canberra: Pacific Linguistics.

Saitou, Naruya, and Masatoshi Nei. I987. The Neighbor-Joining method: A new method for reconstructing phylogenetic trees. Molecular Biology and Evolution 4:406-25.

Schmidt, Annette. 1985. Young people's Dyirbal: An example of language death from Australia. Cambridge: Cambridge University Press.

Sheppard, Peter, Richard Walter, and Shankar Aswani. 2004. Oral tradition and the creation of late prehistory in Roviana Lagoon, Solomon Islands. Records of the Australian Museum Supplement 29: I23-32.

Sheppard, Peter, Richard Walter, and Takuya Nagaoka. 2000. The archaeology of headhunting in Roviana Lagoon, New Georgia. Journal of the Polynesian Society I09:9-37.

Swofford, David. 2003. PAUP*. Phylogenetic analysis using parsimony (*and other methods), version 4.o bIo. Sunderland, MA: Sinauer Associates.

Teeter, Karl V. I958. Review of Lanyon-Orgill An introduction to the Thai (Siamese) language for European students. Journal of the American Oriental Society 78:76-80.

Terrill, Angela. 2002. Systems of nominal classification in East Papuan languages. Oceanic Linguistics 4I:63-88.

Terrill, Angela, and Michael Dunn. 2003. Orthographic design in the Solomon Islands: The social, historical, and linguistic situation of Touo (Baniata). Written languages and literacy 6:177-92.

Thomas, Tim, Peter Sheppard, and Richard Walter. 200I. Landscape, violence and social bodies: Ritualized architecture in a Solomon Islands society. Journal of the Royal Anthropological Institute 7:545-72.

Thurston, William R. I982. A comparative study of Anêm and Lusi. Canberra: Pacific Linguistics.

Tryon, Darrell, and Brian Hackman. 1983. Solomon Island languages: An internal classification. Canberra: Pacific Linguistics.

Vansina, Jan. 1965. Oral tradition. London: Routledge and Kegan Paul.

Walter, Richard, Tim Thomas, and Peter Sheppard. 2004. Cult assemblages and ritual practice in Roviana Lagoon, Solomon Islands. World Archaeology 36: I42-57.

Waterhouse, W. H. L., and S. H. Ray. 1927. The Baniata language of Rendova island. Man 27:64-67.

- I93I. The Kazukuru language of New Georgia. Man 3I:I23-26.

Wurm, Stephen A. I978. Reefs-Santa Cruz: Austronesian, but...! In Second International Conference on Austronesian Linguistics: Proceedings, ed. by S. A. Wurm and Lois Carrington, 969-Io Io. Canberra: Pacific Linguistics.

- I982. Papuan languages of Oceania. Ars Linguistica 7. Tübingen: Gunter Narr Verlag. 


\section{APPENDIX 1. KAZUKURU WORDLIST}

\author{
arrow pito Rov. tupi (metathesis) \\ ascend melasaulo \\ ashes ibe Rov. eba \\ awake vauneu Rov. vanggunu \\ axe taunona Teop torara \\ bad kalenou Rov. kalea-na ( $k a$ - is a \\ negative prefix in Marovo, lea-na is \\ 'good') \\ bamboo hila \\ banana vinovo \\ barter linoga \\ basket sukonou, sukinai \\ belly lea \\ belt rito \\ betel (areca) nut piku \\ big monamona Rov.nomana \\ bird kinoukorurenou Rov. kurukuru tapuru \\ (lit. 'animal fly')
}

black himo

bless it bahoro magalia

blood rinati

body viniti Proto-North-Central Vanuatu

*vinuti ‘skin', POc *punut 'coconut husk'

bone sinori Rov. susuri, POc *suri

bow vejala

bowels sinu

breadfruit runa

break pitokau

breast suno $\mathrm{POc} *$ susu

Bring it! hinani Rov. Hena mai!

burn pitapona

bury pinotu

butterfly pilapila Rov. pepela

chew mesamea

chief zana zana

child rinotu $\mathrm{POc} *$ natu

clean bino

cloud hinu

club vedorou Rov.,Nduke, Kusaghe vedara

coconut voarana POc *paRaq 'coconut embryo'

cold simu Rov. $i b u$

come emo POc *ma

cook miloe creek renou

crocodile bija bija

cut zanuturo

damp siru siru

dance piloke Rov. peka

darkness huhumi

daylight kekeana Minigir (East New

Britain) kesakesa 'sun'

descend molate (see melasaulo 'ascend')

die minata $\mathrm{POc} *$ mate

dig ganelo

do not totoro

dog pilipuo

door siname

draw water rurunu $\mathrm{POc} *$ ranum

'fresh water'

dream putiutue

drink nipo Rov. napo

ear ninoia

earth, soil vunuyo

eat yitayia Rov. yania

egg linono

elbow tuyulu-tina POc *turu 'elbow, knee'

eye meta $\mathrm{POc} *$ mata

face sinu meta < sinu 'bowels', meta 'eye'

father mamato Originally a vocative related to POc *tama 'father'

fear mayayuti Rov. mataguti, $\mathrm{POC}^{*}$ mataqut

feast searajano

feather ginutu-reukenu (see ginutu 'hair')

finger rinurinu

fire hikani Rov. nika (metathesis)

fish mesai Proto-North-Central Vanuatu *mazi

flesh sinimai (is this the same as sininai 'food'?)

flower ruvona

fly (n) zinojo

fly (vb) ripoti

food sininai Rov. ginani, olanene; Hoava nininai

foot neuno Rov.nene

forehead reo Rov. rai, POc *raqe

forest, bush butu vulu 
fruit vutavuta

get up (from lying down) titiutu

give munoa Banoni mana

go liu Lungga, Simbo riu

good linea Rov. leana

ground, land vato vato

hair ginutu

hand vonili

hard vonumo

he, she, it (3SG) sana Rov. sa, asa

head rano

hear inoyo POc *loyor

hill miroro

hot ninonino Rov. ma-nini

POc *ma-nini(t) 'become hot'

house valou POc *pale 'hut, open-sided building', POc *panua 'inhabited area, land, community' (some New Georgia languages also have reflexes of *panua in the meaning 'house')

hurt sirani

husband lajasana

kill rinomu tamuta

know rimoti

leaf piloi

leg nukolou

lie down etikou

lime sineni

lip mono

live ninoto

liver tobe

make fire siku

man memoni

mat hamihami

moon retulu

mother mamano (a nursery form)

mouth nonano

musical instrument sutuno

my lying down moloto gonu

name zeponi

neck nigou

night muni

nose sunu POc *isun

ornaments virosino Rov. vinasari

our houses anumami solu

outrigger float vuya

paddle avi

pig purono Lungga, Nduke boroyo,

POc *borok plant (vb) tulotia

pool suporono

possum hinapouna

rain mekuhu

rain from Kazukuru mekuhu pa

Kazukuru

red erone

river siratisi

road ritani

run quickly kula pinani

sago palm elopena

scratch ritini

see sino

shell ornament ukeana

shield lovino

sing kino

sit hatubua Rov. habuto (metathesis)

sleep pinou

small menilena

soft hinohinoho

speak zino, zinou

spear zatobau Marovo babao 'to go

spear fishing, a fishing spear'

stand ruto Rov. turu (metathesis)

stone pitoni POc *patu

sugar cane mizamiza

sweet sioso

tabu tabuna, maninono Rov. tabu-na, POc *tabu

taro mekohoni

they (3PL) riniai Rov. rini, sarini

thick situnu

thin sinipe $\mathrm{POc} *$ nipis

tie (vb) kurotoni

tongue lepani

tooth titio

tree vutlono

vine, creeper seroi, rorose Rov. aroso

water kiloni Rov. kolo

weed (vb) pitapia

weep kiboni POc *kabo, Rov. kabo

white vine

wind imeime

wing siporoni

woman kazane

yam minono 